E 159.G19 ${ }^{\text {Cornell University Library }}$

The areas of the United States, the stat

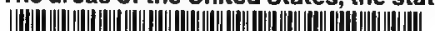

31924014027431 


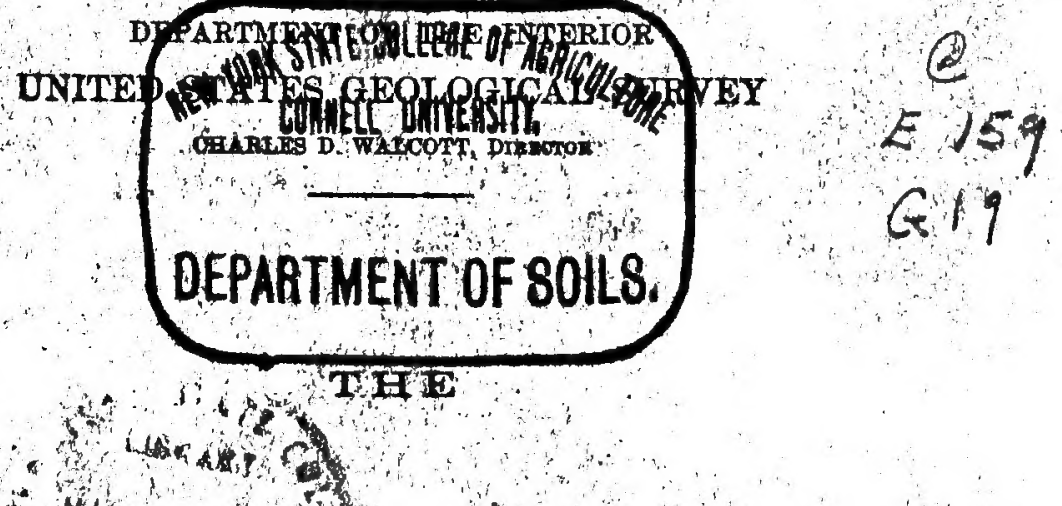

AREAS ON THE NITED STATES, THE STTYES ANDAHE TERRTTORIES

BX

\section{HENTY GANNETT}

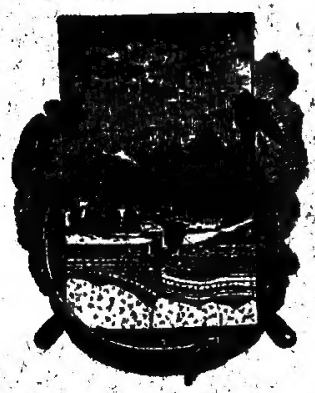

WASHINGTON

GOVENMENTHINTINGOFIOE

1906 


\section{Cornell University Library}

The original of this book is in the Cornell University Library.

There are no known copyright restrictions in the United States on the use of the text.

http://www.archive.org/details/cu31924014027431 
DEPARTIENT OF THE INTERIOR UNITED STATES GEOLOGICAL SURVEY CHARLES D. WALCOTT, DIRECTOR

TH E

\title{
AREAS OF THE UNITED STATES, THE STATES, AND THE TERRITORIES
}

BY

\section{HENRY GANNETT}

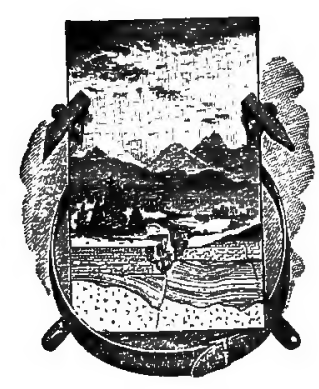

\author{
W A S H I N G TON \\ GOVERNMENT PRINTING OFHICE \\ 1906
}


- (C)

$E 159$
$G 19$ 


\section{ILLUSTRATION.}

Plate I. Map of the United States, defining the adopted limits of the gross

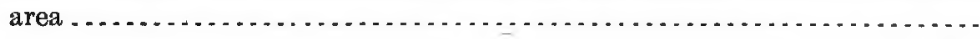






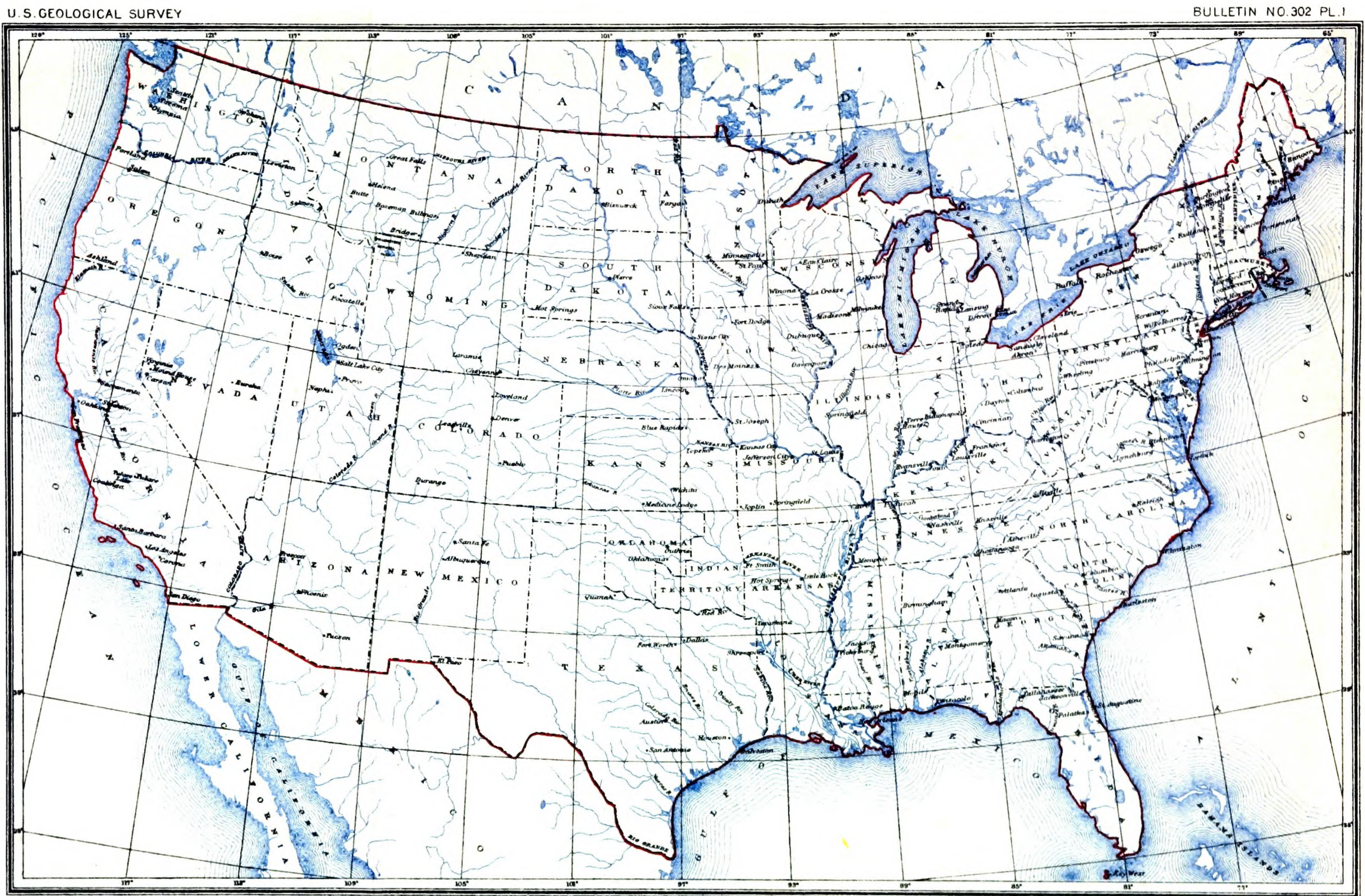

MAP OF THE UNITED STATES, DEFINING THE ADOPTED LIMITS OF THE GROSS AREA JULUS BIEN A COLITH NY

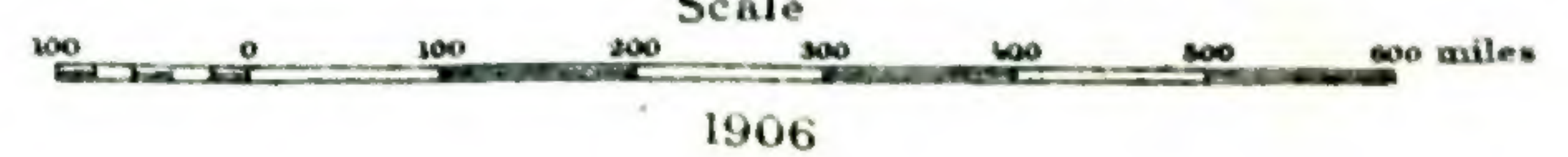





\section{THE AREAS OF THE UNITED STATES, THE STATES, AND THE TERRITORIES.}

\section{By Henry Gannett.}

In 1881 the Census Office published in an extra bulletin tables showing the areas of the United States and of the several States and Territories. The measurements and computations upon which these tables were based were made with care, according to methods described in the bulletin, and the results probably represented the areas as closely as they could be determined from the maps and charts of that time. In 1899 the General Land Office printed similar tables, which were also prepared with great care and thoroughness.

The tables presented in these two publications differ from each other. Most of the differences are trifling, amounting to only a few square miles or a small fraction of 1 per cent, being well within the limits of error of the planimeter and of the maps used. Some of them, however, are considerable, and a few are explained by the fact that more recent maps, which changed the position of boundaries between States, had been used by the Land Office, and its measurement was, therefore, more nearly correct. Other discrepancies arose from differences in determining the cpast lines; as an example of this, the Land Office measurement of the State of Washington included half of the Strait of Juan de Fuca, while that of the Census Office did not, involving a difference in area of 1,500 square miles.

Realizing the desirability of the Government issuing but one statement of areas of the States and Territories, the offices concerned, through their representatives, Mr. Frank Bond, chief draftsman of the General Land Office, Mr. C. S. Slosne, geographer of the Census Office, and myself, representing the Geological Survey, have been at work for several months in the endeavor to come to an agreement on these figures, and in the course of our discussion many new measurements have been made from the most recent and best maps. An agreement has been reached, the results of which are set forth in the accompanying table. 
By this adjustment the area of the United States proper is increased over the Census Office figures by 1,188 square miles, or about three one-hundredths of 1 per cent.

The question, "What constitutes the area of the United States?" is by no means a simple one. Jurisdiction extends to a line 3 nautical miles from the shore, but this strip of sea can not properly be regarded as a part of the country. Supposing our country to be restricted to the sea and lake coast, there remains a question regarding the bays and estuaries. To what extent should the coast line be followed strictly, and where should we begin to jump across the indentations made by the sea? In this matter one can only follow his own judgment, making in each case as natural a decision as possible, as no definite criterion can be established. This applies also to those States bordering the sea and the Great Lakes.

The method of measurement may be characterized in a few words. The areas of all square degrees included entirely within a State or the United States are taken from tables of such areas. Where a square degree is crossed by a boundary line, so that only part of it is included, both the part included and that excluded are measured from the best maps by planimeter, and the correctness of the measurement is tested by comparing their sum with the tabular area of the square degree.

The entire boundary of the United States has now been mapped or charted with accuracy, so that, aside from uncertainties due to the interpretation of the coast line, there can be little or no question as to the correctness of the measurement of the country as a whole. The situation as regards the individual States is not so satisfactory, however, although the boundaries of most of them are now well mapped. Certain States are bounded by parallels and meridians, and the ascertainment of their areas is merely a matter of reference to tables of areas of square degrees, assuming that the boundary lines were accurately run and marked in accordance with the statute. The boundaries of a few of the States, however, have not been accurately mapped, and it is probable that changes will be made in the computed areas of these States.

The area of Alaska, measured in this office from the large Coast Survey chart, is subject to considerable modification in the future as the position of the coast line becomes better known.

The area given for the Philippine Islands is that determined by the Coast Survey of that archipelago, prepared at the instance of the Philippine Census and published in that report. It also is subject to modification as accurate charts of the archipelago are made.

The areas of Hawaii and Porto Rico are probably subject to only slight change, as the charts from which they were measured are quite accurate. 
The areas given for the other small possessions of the United States-Guam, Samoa, and the Panama Canal strip-will probably be changed in the future as their limits become more correctly defined.

Areas, in square miles, of the States and Territories.

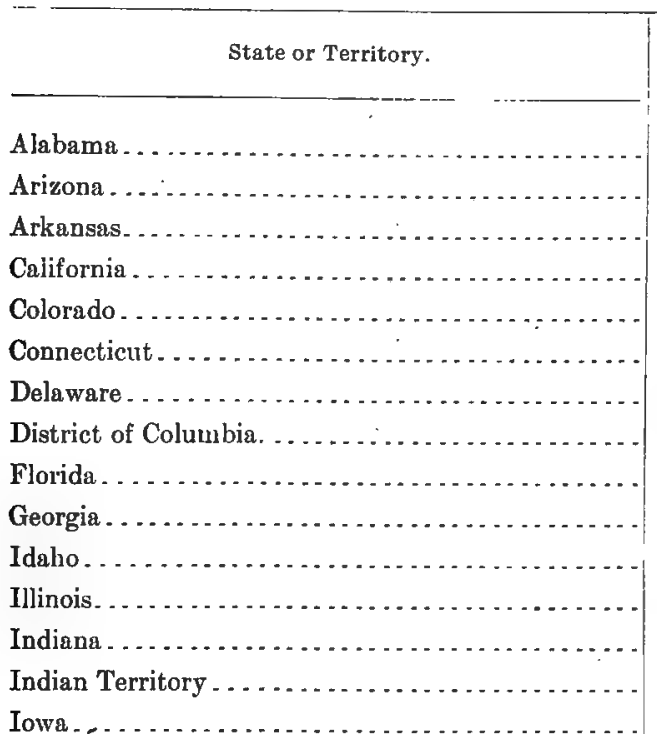

Kansas .

Kentucky . . .

Louisiana

Maine

Maryland

\begin{tabular}{|c|c|c|}
\hline Land surface. & $\begin{array}{c}\text { Water } \\
\text { surface. }\end{array}$ & Total a rea. \\
\hline 51,279 & 719 & 51,998 \\
\hline 113,840 & 116 & 113,956 \\
\hline 52,525 & 810 & 53,335 \\
\hline 156,092 & 2,205 & 158,297 \\
\hline 103,658 & 290 & 103,948 \\
\hline 4,820 & 145 & 4,965 \\
\hline 1,965 & 405 & 2,370 \\
\hline 60 & 10 & 70 \\
\hline 54,861 & 3,805 & 58,666 \\
\hline 58,725 & 540 & 59,265 \\
\hline 83,779 & 534 & 84,313 \\
\hline 56,002 & 663 & 56,665 \\
\hline 35,885 & 469 & 36,354 \\
\hline 30,790 & 419 & 31,209 \\
\hline 55,586 & 561 & 56,147 \\
\hline 81,774 & 384 & 82,158 \\
\hline 40,181 & 417 & 40,598 \\
\hline 45,409 & 3,097 & 48,506 \\
\hline 29,895 & 3,145 & 33,040 \\
\hline 9,941 & 2,386 & 12,327 \\
\hline 8,039 & 227 & 8,266 \\
\hline 57,480 & 500 & 57,980 \\
\hline 80,858 & 3,824 & 84,682 \\
\hline 46,362 & 503 & 46,865 \\
\hline 68,727 & 693 & 69,420 \\
\hline 145,776 & 796 & 146,572 \\
\hline 76,808 & 712 & 77,520 \\
\hline 109,821 & 869 & 110,690 \\
\hline 9,031 & 310 & 9,341 \\
\hline 7,514 & 710 & 8,224 \\
\hline 122,503 & 131 & 122,634 \\
\hline 47,654 & 1,550 & 49,204 \\
\hline 48,740 & 3,686 & 52,426 \\
\hline 70,183 & 654 & 70,837 \\
\hline 40,740 & 300 & 41,040 \\
\hline 38,624 & 224 & 38,848 \\
\hline
\end{tabular}

Massachusetts.

Michigan -

Minnesota

Mississippi. .

Missouri

Montana

Nebraska .

Nevada

New Hampshire.

New Jersey

New Mexico

New York

North Carolina

North Dakota

Ohio

Oklahoma Territory ; 
Areas, in square miles, of the States and Territories-Continued.

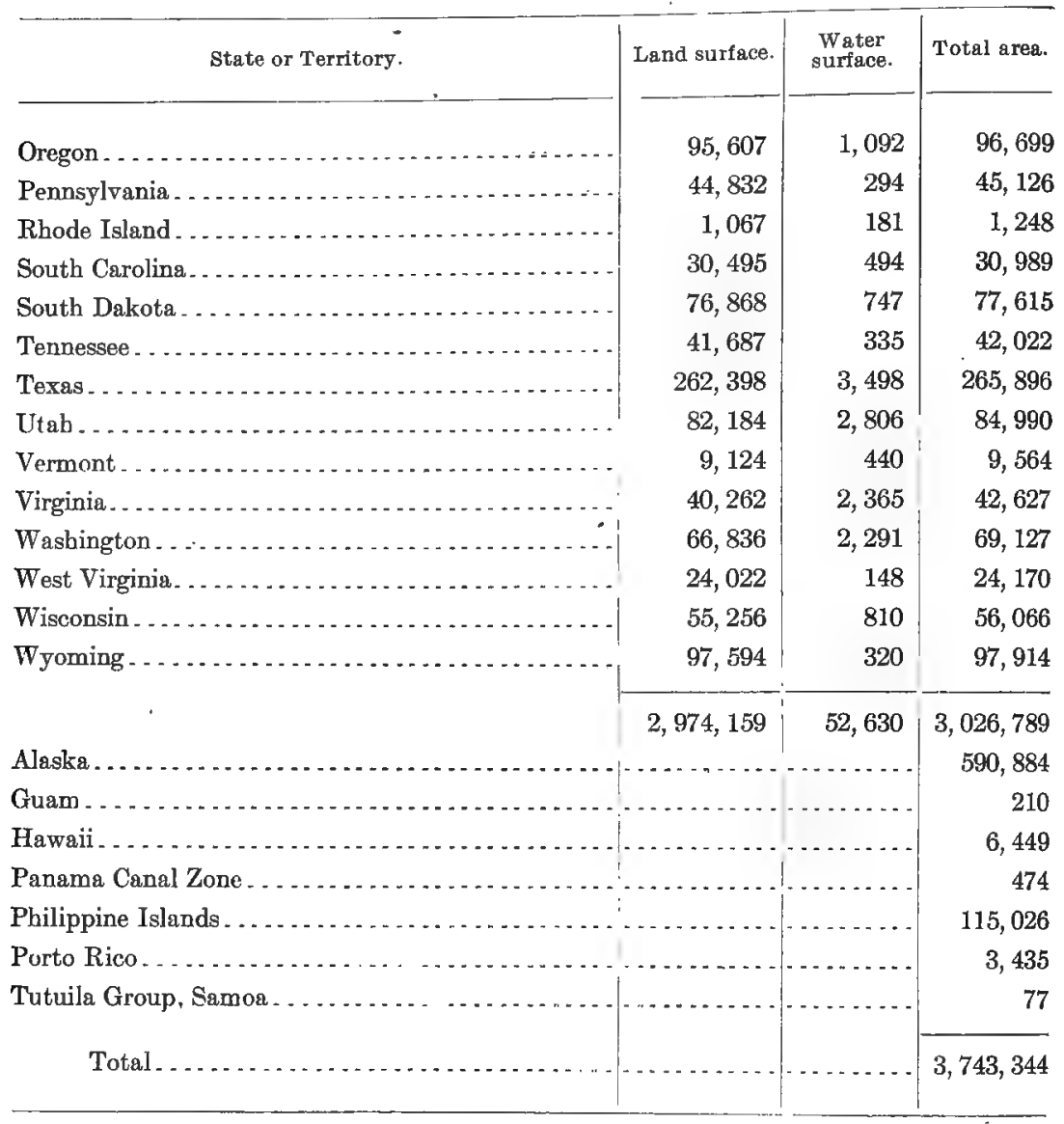

Owing to their location adjoining the Great Lakes, the States enumerated below contain approximately an additional number of square miles as follows:

Dlinois

Indiane

Michigan

Minnesota

New York

Ohio

Pennsylvania

Wisconsin
1,674 square miles of Lake Michigan.

230 square miles of Lake Michigan. 16,653 square miles of Lake Superior. 12,922 square miles of Lake Michigan.

9,925 square miles of Lrke Huron.

460 square miles of Lakes St. Clair and Erie.

2,514 square miles of Lake Superior.

3,140 square miles of Lakes Ontario and Erie. 3,443 square miles of Lake Erie.

891 square miles of Lake Erie.

2,378 square miles of Lake Superior. 7,500 square miles of Lake Michigan. 
In addition to the water areas noted above, California claums jurisdiction over all Pacific waters lying within 3 English miles of her coast; Oregon claims jurisdiction over a similar strip of the Pacific Ocean 1 marine league in width between latitude $42^{\circ} \mathrm{N}$. and the mouth of the Columbia River; and Texas claims jurisdiction over a strip of Gulf water 3 leagues in width, adjacent to her coast between the Rio Grande and the Sabine River. 



\section{CLASSIFICATION OF THE PUBLICATIONS OF THE UNITED STATES GEOLOGICAL SURVEY.}

[Bulletin No. 302.]

The publications of the United States Geological Survey consist of (1) Annual Reports; (2) Monographs; (3) Professional Papers; (4) Bulletins; (5) Mineral Resources; (6) Water-Supply and Irrigation Papers; (7) Topographic A tlas of United Stater-folios and separate sheets thereof; (8) Geologic Atlas on United States-folios thereof. The classes numbered 2,7 , and 8 are sold at cost of publication; the others are rlistributed free. A circular giving complete lists may be had on application.

Most of the above publications may be obtained or consulted in the following ways:

1. A limited number are delivered to the Director of the Survey, from whom they may be obtained, free of charge (except classes 2, 7, and 8), on application.

2. A certain number are delivered to Senators and Representatives in Congress, for distribution.

3. Other copies are deposited with the Superintendent of Documents, Washington, D. C., from whom they may be had at prices slightly above cost.

4. Copies of all Government publications are furnished to the principal public libraries in the large cities throughout the United States, where they may be consulted by those interested.

The Professional Papers, Bulletins, and Water-Supply Papers treat of a variety of subjects, and the total number issued is large. They have therefore been classified into the following series: A, Economic geology; B, Descriptive geology; C, Systematic geology and paleontology; D, Petrography and mineralogy; E, Chemistry and phyrics; F, Geography; G, Miscellaneous; H, Forestry; I, Irrigation; J, Water storage; $\mathrm{K}$, Pumping water; $\mathrm{L}$, Quality of water; $\mathrm{M}$, General hydrographic investigation:; N, Water power; (), Underground waters; P, Hydrographic progress reports. This paper is the fifty-third in Series $F$, the complete list of which follows (all are bulletins thus far except Professional Paper 45):

\section{SERIES F, GEOGRAPHY.}

5. Dictionary of altitudes in Enited States, by Henry Gannett. 1६४४. 325 pp. (Ont of stock; sce Bulletin 274.)

6. Elevations in Dominion of Canada, by J. W. Spencer. 1K5t. 43 pp. (Out of stock.)

13. Boundarie of Inited States and of the several States and Territories, with historical sketeh of territorial changes, by Henry Gannett. 1885. $135 \mathrm{pp.} \mathrm{(Out} \mathrm{of} \mathrm{stock;} \mathrm{see} \mathrm{Bulletin} \mathrm{226.)}$

4.. On form and position of sea level, by R. S. Woodward. 1888. $88 \mathrm{pp.}$ (Out of stock.)

49. Latitudes and longitudes of certain points in Miswouri, Kansas, and New Mexiro. by R. $\therefore$. Woodward. $1889.133 \mathrm{pp}$.

50. Formulas and ta'oles to fucilitate the construction and usc of maps, by $\mathbf{R}$. S. Wontward. 1889. $124 \mathrm{pp}$. (Out of stock.)

70. Report on astronomical work of 1889 and $1890, b y$ R. $A$, Woodward. $1890.79 \mathrm{pp}$.

72. Altitudes between Lake Superior and Rocky Iountains, by Warren Ipham. 1891. 224, Ip.

7i. I Detionary of altitudes in Tnited States (second edition), by Henry Gannett. 1891. 393 pp. (Out of stuck; see Bulletin 274 .)

115. Geographic dictionary of Rhode Island, by Henry Gannett. 1894. 31 pp.

11i. Geographic dictionary of Massachusetts, by Henry Gannett. 1894, $126 \mathrm{pp}$.

117. Geographic dictionary of Connecticut, by Henry Gannett. 1×44. $67 \mathrm{pp}$.

118. Geographic dictionary of New Jersey, by Henry Gannett. 1894. 131 pp.

122. Results of primary triangulation, by Henry Gannett. 1894.412 pp., 17 pls. (Out of stock.)

123. Dictionary of geographic positions, by Henry Gannett. 1895. 183 pp., 1 map. (Out of stock.)

154. Gazetteer of Kansas, by Henry Gannett. 1898. 246 pp., b pls. 






